\title{
The design and construction of project-based teaching model with the view of "double innovation"- Based on case study of commercial bank management
}

\author{
Xi Yang \\ Dongfang College, Shandong University of Finance and Economics, Taian Shandong, 271000, China
}

Keywords: “Double innovation” education, Project-based teaching, Commercial bank management "gray correlation evaluation model.

\begin{abstract}
In September 2014, Premier Li Keqiang firstly proposed the "public entrepreneurship, innovation" strategic thought, in 2015, the general office of the State Council issued the implement opinions on deepening the reform of higher education, the concrete measures are to deepen the reform of education in a new venture forward from nine aspects. The Ministry of education requires that all colleges and universities should set up innovative entrepreneurship education courses from 2016. In 2016, China's innovation and entrepreneurship education showed a blowout development trend. In this paper, the teaching reform of "science" course of commercial banks as the starting point, discusses how to stimulate students' innovation consciousness education under the current background of "double innovation", to cultivate applied talents with high comprehensive quality, innovation ability.
\end{abstract}

\section{Introduction}

In May 2015 the State Council issued implement opinions on deepening the reform of higher education, put forward clear requirements from nine aspects of the personnel training mechanism, teaching methods and assessment methods, innovation course system and practice of innovation and entrepreneurship, innovation and entrepreneurship education in Colleges and universities education .In 2016, China's innovation and entrepreneurship education showed a trend of blowout development. The Ministry of education requires that all colleges and universities should set up innovative entrepreneurship education courses from 2016. According to Ministry of education statistics, currently more than $80 \%$ of the national colleges and universities entrepreneurship education curriculum innovation and the establishment of innovation base, the establishment of innovation funds reached up to 1.22 billion yuan, students who participate in the business innovation activities reached more than 3million. At present, how to put double innovation management education into the existing teaching system, which can not only the current social demand, but also highlight the school characteristics, exercise students' subjective initiative has become a key point in the reform of entrepreneurship education in Colleges and Universities .

\section{The value and significance of the project-based teaching method of college education management reform}

Project-based teaching, in short, is the development of teaching activities through the completion of projects. It takes deconstructionism as the theoretical basis, emphasizes the construction of knowledge system with students as the main guide, and changes the original indoctrination education mode. Guided by specific projects and run through the whole process of teaching, we can implement the teaching tasks more targeted, and more emphasis on the difficulties and difficulties of the specialized knowledge. The purpose of teaching is more clear. The significance of project-based teaching is mainly embodied in the following three aspects:

In points of teacher, they are no longer simple knowledge delivery person, they are also the guider 
and partner of student during study. In this process, teachers can see clearly the advantages and disadvantages of each student, and students can carry out more communication and exchange, to change the former teaching teachers only teach knowledge and students lack of interactive communication problems .

For students, In active learning environment, through a variety of projects to stimulate interest in learning and exploring spirit, to complete the information collection, literature review, investigation and analysis and discussion to form the defense team practice and creative activities, students' innovative spirit and entrepreneurial ability can br cultivated.

For school, the implementation of project based teaching method, can establish a new curriculum concept, the management of education and better integrated into the existing curriculum system, and gradually improve the re integration of the school curriculum system.

\section{Application of project-based teaching model: a case study of commercial bank management \\ The teaching characteristics and existing problems of commercial banks' management}

Commercial bank management course is a required major course for finance majors in finance and economics colleges. It is an applied course closely related to theory. The content of the course includes both the basic theory and specific business of commercial banks. At the same time, we should pay more attention to the development of the financial field and the innovations of the commercial banks. The course has the characteristics of comprehensiveness, application and practice. It can stimulate students' enthusiasm for learning and develop students' innovative spirit.

In the teaching process of colleges and universities at present, due to time and curriculum constraints, most of the time, is mainly by teachers' teaching, teaching is usually one-way and passive, students follow the ideas of teachers, lack of independent thinking and the spirit of exploration, the students lack interest in learning and initiative. At present, the rate of absenteeism in college is high, and the phenomenon of students playing mobile phones, chatting and sleeping is quite common, and the quality of classroom is worrying. In order to fundamentally solve these problems, we must first change the teaching idea, change teaching mode, constructing the passionate and challenging atmosphere of classroom teaching, guide students to actively construct knowledge system, improve the professional quality, laying a solid foundation for professional, ready for business.

\section{Design and construction of project-based teaching model}

The key lies in constructing the teaching process must maintain the dominant position of the students of project teaching model, teachers are just guides and mentors, good instructional design, enable students to achieve the teaching goal in the process of completion of the project requirements. The following is to explain the construction and application of project teaching method in the actual teaching with the example of commercial bank management, which the author teaches

Commercial bank management teaching project in the natural class as the foundation, take the way of team cooperation, voluntary groups, division of labor, through the completion of the project tasks, knowledge construction and ability improvement. Detailed steps are followed :

Design project themes according to syllabus requirements.

According to the "commercial bank management" syllabus requirements, teacher will design several project topic by teachers, students determine the project theme in group discussion, and finally decide project tops after discussed with teacher.

According to the syllabus and the teaching plan arrangement, combining the economic hot spot and the latest development of the financial industry, designed 5 project tasks throughout the curriculum teaching. In addition, students can always refer to the latest economic trends, select courses related to the content of the news theme broadcast, PPT media, such as the way to report, display, you can also add scores to process assessment scores. The number of business teaching in commercial banks is 17 weeks, totaling 51 hours, and the contents of specific projects are as follows : 
Table 1. Detailed arrangement for project based commercial bank management teaching

\begin{tabular}{|c|c|c|c|}
\hline Project them & Time plan & Project requirement & $\begin{array}{l}\text { project achievement } \\
\text { form }\end{array}$ \\
\hline $\begin{array}{l}\text { The development of financial } \\
\text { technology (Fintech) and the } \\
\text { global banking reform }\end{array}$ & Week 2-4 & $\begin{array}{l}\text { Facing the rapid development of } \\
\text { financial science and technology and } \\
\text { the major changes in the global } \\
\text { banking industry, discuss the } \\
\text { countermeasures for the } \\
\text { transformation and development of } \\
\text { China's commercial banks }\end{array}$ & PP and presentation \\
\hline $\begin{array}{l}\text { The calculation principle of } \\
\text { LCR supervision index and its } \\
\text { implementation in China }\end{array}$ & Week 5-7 & $\begin{array}{l}\text { Combined with the requirements of } \\
\text { the Basel Agreement III and the } \\
\text { specific provisions of our country, } \\
\text { discuss the impact of LCR } \\
\text { examination on commercial banks }\end{array}$ & PP and presentation \\
\hline $\begin{array}{l}\text { Development and supervision } \\
\text { of Internet banking in China }\end{array}$ & Week 8-10 & $\begin{array}{c}\text { Survey the development of Internet } \\
\text { banking in China, analyze the existing } \\
\text { problems and discuss the } \\
\text { countermeasures and suggestions }\end{array}$ & $\begin{array}{l}\text { Investigation report, } \\
\text { PP and presentation }\end{array}$ \\
\hline $\begin{array}{l}\text { The present situation } \\
\text { and disposal methods of } \\
\text { non-performing loans of } \\
\text { commercial banks in China }\end{array}$ & Week 11-13 & $\begin{array}{l}\text { Investigate the non-performing loan } \\
\text { data of } 25 \text { listed banks in China, and } \\
\text { discuss the disposal of non-performing } \\
\text { assets in combination with asset } \\
\text { securitization }\end{array}$ & $\begin{array}{l}\text { Investigation report, } \\
\text { PP and presentation }\end{array}$ \\
\hline $\begin{array}{l}\text { The development of new } \\
\text { consumption finance in China }\end{array}$ & Week 14-16 & $\begin{array}{l}\text { Survey of the development of new } \\
\text { consumer finance in China, starting } \\
\text { with the needs of college students, } \\
\text { design a consumer financial products }\end{array}$ & $\begin{array}{l}\text { Design survey PP } \\
\text { and presentation }\end{array}$ \\
\hline
\end{tabular}

\section{Project task completed by groups}

Each group will communicate and discuss with each other in accordance with the selected topics, and team members will work together to accomplish the project. The results of the project can be shown by taking video clips, PPT and other multimedia methods, or writing related papers for publication. Other members of the group may present their own queries and insights at the scheduled time during the class presentation. Through questioning, digging the depth and breadth of the project, to guide students to innovative thinking, divergent thinking. Teachers can evaluate and evaluate students according to their performance, and explain the advantages and disadvantages of each group in light of relevant theoretical knowledge and relevant hot spots at home and abroad.

\section{Comprehensive evaluation of group project results}

According to the completion of the project and the specific performance of students, comprehensive evaluation of each group was conducted. The evaluation part of the gray correlation evaluation model, the evaluation of teachers, set up 6 indicators of team performance and evaluation of students in three aspects, to represent the attendance, classroom questioning, group discussion, project report, PPT and multimedia production and peer group, selected the experimental class as a sample for calculation. Of which, correlation index $X_{i}$ observations are expressed as $X_{i}=\left\{x_{i}(1), x_{i}(2), \cdots x_{i}(k), \cdots x_{i}(n)\right\} i=1,2,3 \cdots 6 ; k=1,2,3 \cdots 5$, while relevant optimal value by relative optimal value of each evaluation index should be choose as Optimum reference index $X_{0}: X_{0}=\left\{x_{0}(1), x_{0}(2), \cdots x_{0}(k), \cdots x_{0}(n)\right\}$, when the observation value of $x_{i}$ in $X_{i}$ is positive 
indicators , $x_{0}(k)=\max _{i} x_{i}(k)$;hen the observation value of $x_{i}$ in $X_{i}$ is negative indicators, $x_{0}(k)=\min _{i} x_{i}(k)$

Summary of relevant data can be obtained as follows :

Table 2. Original data

\begin{tabular}{|c|c|c|c|c|c|c|c|}
\hline Variables & Group one & Group two & Group three & Group four & Group five & Group six & reference value \\
\hline$x_{1}$ & 100 & 95 & 90 & 100 & 100 & 100 & 100 \\
\hline$x_{2}$ & 90 & 95 & 85 & 95 & 90 & 90 & 95 \\
\hline$x_{3}$ & 90 & 80 & 85 & 95 & 90 & 90 & 95 \\
\hline$x_{4}$ & 80 & 80 & 80 & 90 & 85 & 85 & 90 \\
\hline$x_{5}$ & 95 & 80 & 85 & 85 & 95 & 90 & 95 \\
\hline$x_{6}$ & 80 & 75 & 70 & 80 & 85 & 85 & 85 \\
\hline
\end{tabular}

The correlation coefficient $x_{0}(k)$ and $x_{i}(k)$ will be marked as $\xi_{i}(k)$, it can expressed as $\xi_{\mathrm{i}}(k)=\frac{\min _{i} \min _{k}\left|x_{0}(k)-x_{i}(k)\right|+\rho \bullet \max _{i} \max _{k}\left|x_{0}(k)-x_{i}(k)\right|}{\left|x_{0}(k)-x_{i}(k)\right|+\rho \bullet \max _{i} \max _{k}\left|x_{0}(k)-x_{i}(k)\right|}$

Of which $\left|x_{0}(k)-x_{i}(k)\right|=\Delta_{i}(k), \min _{i} \min _{k}\left|x_{0}(k)-x_{i}(k)\right|$ Is the two lowest difference, $\max _{i} \max _{k}\left|x_{0}(k)-x_{i}(k)\right|$ is two mixed difference, $\rho$ is resolution ratio,value is between $(0,1)$, in general $\rho=0.5$. According to the expression of correlation coefficient, the table of correlation coefficients can be calculated, as shown below:

Table 3. Correlation coefficient of each variable

\begin{tabular}{|c|c|c|c|c|c|c|}
\hline Variable & Group Pne & Group two & Group Three & Group Four & Group five & Group Six \\
\hline$\xi_{1}$ & 1.00 & 0.60 & 0.43 & 1.00 & 1.00 & 1.00 \\
\hline$\xi_{2}$ & 0.60 & 1.00 & 0.43 & 1.00 & 0.60 & 0.60 \\
\hline$\xi_{3}$ & 0.60 & 0.33 & 0.43 & 1.00 & 0.60 & 0.60 \\
\hline$\xi_{4}$ & 0.43 & 0.43 & 0.43 & 0.33 & 0.60 & 0.60 \\
\hline$\xi_{5}$ & 1.00 & 0.33 & 0.43 & 0.43 & 1.00 & 0.60 \\
\hline$\xi_{6}$ & 0.60 & 0.43 & 0.33 & 0.60 & 1.00 & 1.00 \\
\hline
\end{tabular}

Relational grade synthetic evaluation index $X_{i} X_{0}$ should be market as ${ }^{r_{i}}$, formula will be $r_{i}=\frac{1}{n} \sum_{k=1}^{6} \xi_{i}(k)$

,after calculation , $r_{1}=0.71, r_{2}=0.52, r_{3}=0.41, r_{4}=0.73, r_{5}=0.8, r_{6}=0.73$,between $[0,1]$, bigger the value, better performance of the group, higher the grade.

\section{The thoughts and suggestion on implementation of project-based teaching}

In summary, the project based teaching of commercial banks has received positive response from students and achieved good teaching results. In the whole process of teaching reform, the teaching team has encountered a variety of problems, but also accumulated a lot of experience. Summary of teaching is shown as follows, for reference

\section{The project-oriented teaching model puts forward higher requirements for teachers}

In project-based teaching, teachers should not only have high teaching level, scientific research level, grasp the forefront of the development of the industry, but also have a strong ability to control, 
organize and manage the classroom ability. In the course of teaching, the teacher should first analyze the teaching content thoroughly, extract the essence, and explain the key points and difficulties in a limited period of time. In the course of group selection, it can guide the students to carry out effective group discussions, seize the main points of the project and draw up a good topic. When carrying out the project achievements in the group, we should objectively evaluate the students' performance, find out the existing problems, excavate the feasibility of the project and guide the students to write and publish the papers. Therefore, it is not recommended for the new teachers who have just begun to contact classroom teaching

\section{The smooth development of project-based teaching is closely related to the characteristics of students in different classes}

Students of different grades and different classes have great differences in their learning ability, class atmosphere and style of study. Some active class in the class, the students willing to innovate, to show themselves; and some classes are boring, accustomed to echo what the books say, follow the prescribed order. Carry out project teaching needs to design individualized teaching according to different teaching subjects, teaching classes such as APP blue Moyun, through a variety of teaching methods to guide and inspire students to actively participate in classroom teaching, increase teacher-student interaction and communication. But if the class atmosphere is too quiet, the students are not willing to participate in interactive activities, the project is not suitable to do things carelessly, carry out project teaching activities.

\section{Project teaching should pay attention to the communication and discussion among students, especially among groups}

In the project achievement demonstration stage, each group is required to report the results of the project by means of recording video or PPT, etc., and develop the students' ability to express themselves and express themselves. After the completion of the report, teachers and other groups of students ask questions and cross evaluation among groups, more questioning, more exploration, encouraging students to explore and innovate, and brainstorming. Inspire students to carry out further research.

\section{Reference}

[1] Shang Jun. Construction of curriculum system for college students' innovation and entrepreneurship education, Educational exploration, 2015, (9).

[2] Feng Feng, Yuan Zhengfeng, Zhang Jing, et al. A brief analysis of the reform of the curriculum management and education reform of commercial banks, Journal of Shanxi Cadre College of Economic Management, 2015, (3).

[3] Du Yanfei, Zhang Wei. "Dividing the classroom": practice and Reflection on the reform of college classroom teaching mode, Research on continuing education, 2016, (03).

[4] Wang Deying. Research on the innovation of commercial banking network management based on career role orientation, Vocational education communication, 2016, (12).

[5] Li Lianying, sun Zhuo. Exploration and practice of innovation and entrepreneurship education in Universities from the perspective of multidimensional system, Intelligence, 2016, (7). 